\title{
EGY-CIKLUSÚ, KÖZELI INFRAVÖRÖS LÉZERIMPULZUSSAL VEZÉRELT ALAGUTAZÁSOS IONIZÁCIÓ FÁZISTERES VIZSGÁLATA
}

\author{
Hack Szabolcs1, Majorosi Szilárd², Benedict Mihály², Varró Sándor ${ }^{1,3}$ és Czirják Attila ${ }^{1,2}$ \\ ${ }^{1}$ ELI-ALPS, Szeged, Magyarország \\ ${ }^{2}$ Szegedi Tudományegyetem, Elméleti Fizikai Tanszék, Szeged, Magyarország \\ ${ }^{3}$ Wigner Fizikai Kutatóközpont, Szilárdtestfizikai és Optikai Intézet, Budapest, Magyarország
}

DOI: https://doi.org/10.14232/kvantumelektronika.9.13

\section{Bevezetés}

$\mathrm{Az}$ atomok erős lézertérben történő ionizációja alapvető szerepet játszik az attoszekundumos fizikában [1]: egy elegendően nagy intenzitású lézerimpulzus hatására az elektron atomi kötött állapotából (általában alagutazással) a kontinuumba távozhat. Ez a rendkívül sikeres „három-lépéses modell" első lépése, amely a magas rendü harmonikus keltés és számos attoszekundumos mérés és eljárás elméleti alapja. Jelenleg az alagutazási idő [2] és az alagútból való kilépést jellemző impulzus az alagutazásos ionizáció alapvető fontosságú problémái, mind a kvantumelmélet, mind az attoszekundumos fizikában jellemző kísérleti eredmények értelmezése szempontjából. Az elmúlt években több csoport publikált releváns kísérleti eredményeket [3-7], általában az ,attoclock” módszerrel. Bár ezeknek a méréseknek az értelmezése általában nehéz, és vannak ellentmondások is, a cirkulárisan polarizált lézerimpulzussal atomi hidrogén esetén kapott legújabb mérési eredmények [7] megegyezni látszanak a korábbi elméleti eredménnyel [8,9], miszerint nincs késés a lézerimpulzus csúcsa és az elektronnak az alagút kijáratánál történő megjelenése között.

Kevésbé felderítettek az alagutazásos ionizáció ilyen részletei lineárisan polarizált lézerimpulzus esetén, annak ellenére, hogy ez a legelterjedtebb módszer izolált attoszekundumos impulzusok előállítására: ha a lézerimpulzus elektromos térerőssége csak a fö csúcsot tartalmazó félciklus alatt halad meg egy bizonyos küszöbértéket [10], akkor az alagutazásos ionizáció gyakorlatilag csak ebben a félciklusban lehetséges.

Jelen közleményünkben egyetlen atomnak egy lineárisan polarizált lézerimpulzus hatására történő alagutazásos ionizációját elemezzük a klasszikus fázistéren a Wigner-függvény segítségével. Így a korábbiaknál jobb klasszikus elektronpályákat kaphatunk, amelyek a kvantum-momentum függvényen alapuló kezdő impulzussal indulnak, és nagyon jól egyeznek a későbbi kvantumos időfejlődéssel is. Atomi egységeket használunk.

\section{Elméleti modell és numerikus szimulációk}

Egy egyszerűsített elméleti modell keretein belül dolgozunk: dipól-közelítést használunk az egyetlen aktív elektronnal rendelkező atom és a klasszikus elektromágneses mező kölcsönhatásának leírására, ún. hossz-mértékben. A közeli infravörös lézerimpulzus elektromos terét szinusz-négyzet burkolóval modellezzük, a lineáris polarizáció iránya a z-tengely:

$$
E_{z}(t)=F \cdot \sin ^{2}\left(\frac{\pi t}{N T}\right) \cos \left(\frac{2 \pi t}{T}+\phi\right)
$$

itt $F$ a térerősség csúcsértéke, $N$ az impulzus $T$ periódusidejü optikai ciklusainak száma, $\phi$ pedig a vivő-burkoló fáziskülönbség (CEP). Jelen munkánkban $F=0.06, N=3, T=110(\mathrm{ami} \mathrm{kb} .800 \mathrm{~nm}$ központi hullámhossznak felel meg) és $\phi=0$. Ezekkel a paraméterekkel a lézerimpulzus időbeli hossza (intenzitás félértékszélességben) a periódusidő közelében van, azaz közel egy-ciklusú. 
Ez a lézerimpulzus gerjeszti a hidrogénatomot, amely kezdetben alapállapotban van. Az elektron hullámfüggvénye mindvégig független marad a z-tengely körüli azimutális szögtől, ezért a háromdimenziós (3D) időfüggő Schrödinger-egyenletet célszerüen henger-koordinátarendszerben írjuk fel, rögzített atommagot feltételezve:

$$
i \frac{\partial}{\partial t} \Psi(z, \rho, t)=\left[-\frac{1}{2}\left(\frac{\partial^{2}}{\partial z^{2}}+\frac{\partial^{2}}{\partial \rho^{2}}+\frac{1}{\rho} \frac{\partial}{\partial \rho}\right)-\frac{1}{\sqrt{z^{2}+\rho^{2}}}+E_{z}(t) z\right] \Psi(z, \rho, t)
$$

A közelmúltban kifejlesztett algoritmusunk [11] térben és időben negyedrendben pontosan oldja meg numerikusan a fenti egyenletet, a Coulomb-szingularitást peremfeltétellel figyelembe véve. A lézerimpulzus csúcsértékét úgy állítottuk be, hogy a Keldysh-paraméter mindvégig 1 alatt maradjon és a csúcs közelében közel 1 legyen, így az alagutazásos ionizáció a teljes impulzus alatt lehetséges legyen, ugyanis ez a releváns a gáz-HHG jelenleg használatos kísérleti technikái szempontjából.

Mivel a lényeges kvantumos dinamika a lézer polarizációs irányában történik, és a fázisteres elemzés 1-dimenzióban (1D) a legkönnyebben áttekinthető, kiszámítjuk az (általában kevert) 1D-re redukált kvantumállapot sürüségmátrixát a z-tengely mentén a 3D numerikus megoldásból

$$
\varrho\left(z, z^{\prime}, t\right)=2 \pi \int_{0}^{\infty} \Psi^{*}(z, \rho, t) \Psi\left(z^{\prime}, \rho, t\right) \rho d \rho
$$

amiből az alábbi definíció szerint számítjuk ki a Wigner-függvényt:

$$
W\left(z, p_{z}, t\right)=\frac{1}{\pi} \int_{-\infty}^{\infty} \varrho(z+\zeta, z-\zeta, t) \exp \left(2 i p_{z} \zeta\right) d \zeta
$$

A Wigner-függvényt, negatív értékei és nem-klasszikus mozgásegyenlete miatt, általánosan nem lehet klasszikus fázistér-eloszlásként értelmezni. Azonban a Wigner-függvény alábbi

$$
P_{n}(z, t)=\int_{-\infty}^{\infty} p_{z}^{n} W\left(z, p_{z}, t\right) d p_{z}
$$

momentumai alapján kiszámolhatunk egy helytől függő átlagos impulzus az alábbi definícióval:

$$
q(z, t)=\frac{P_{1}(z, t)}{P_{0}(z, t)}
$$

amelyet általában kvantum-momentum függvénynek szokás nevezni. Ez a fizikai mennyiség, hasonlóan a valószínüségi áramsürüséghez, nem additív: két kvantumállapot szuperpozíciója esetén az eredő kvantum-momentum függvényben általában interferencia-tagok is fellépnek. 
(a)

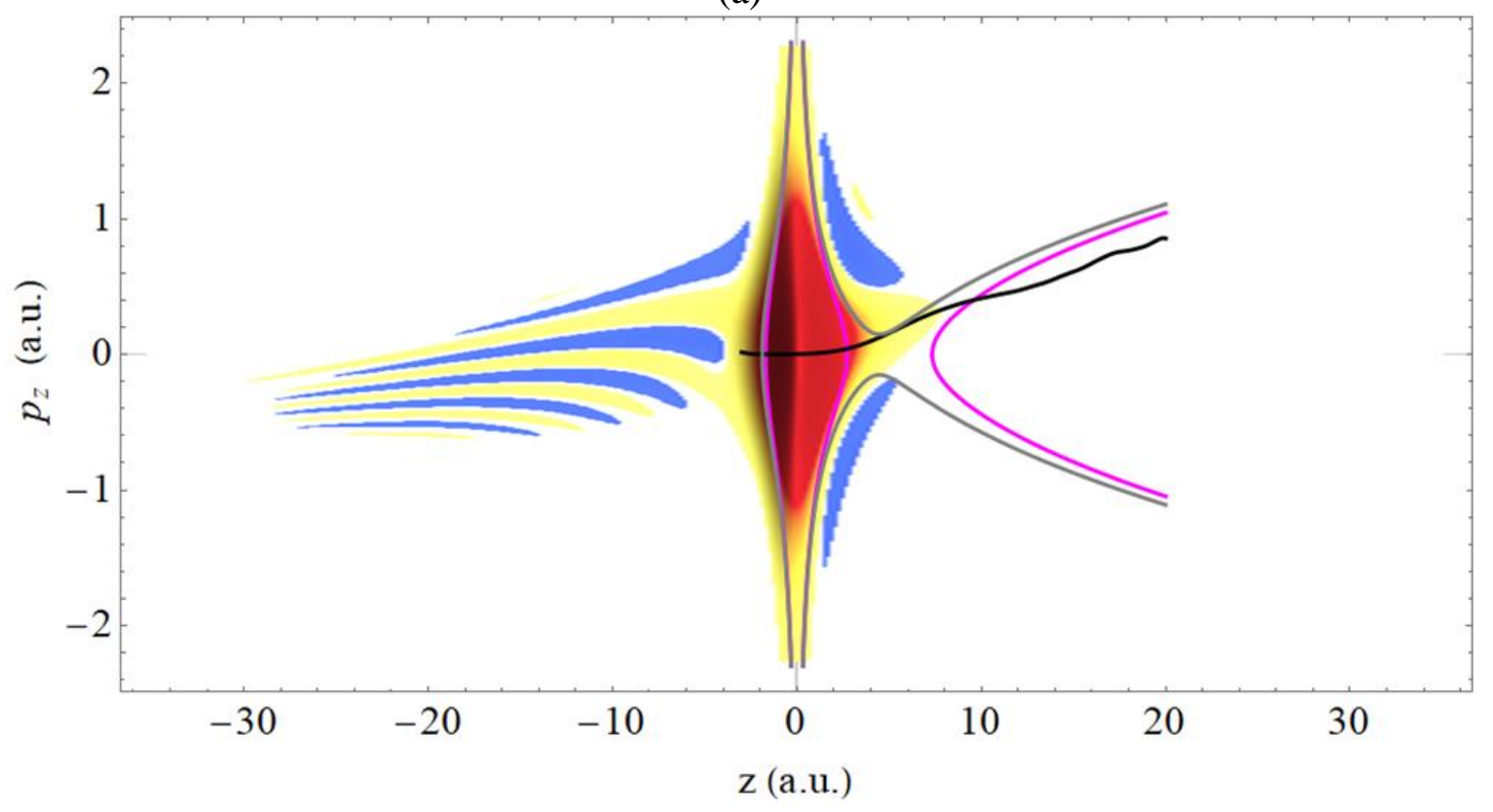

(b)

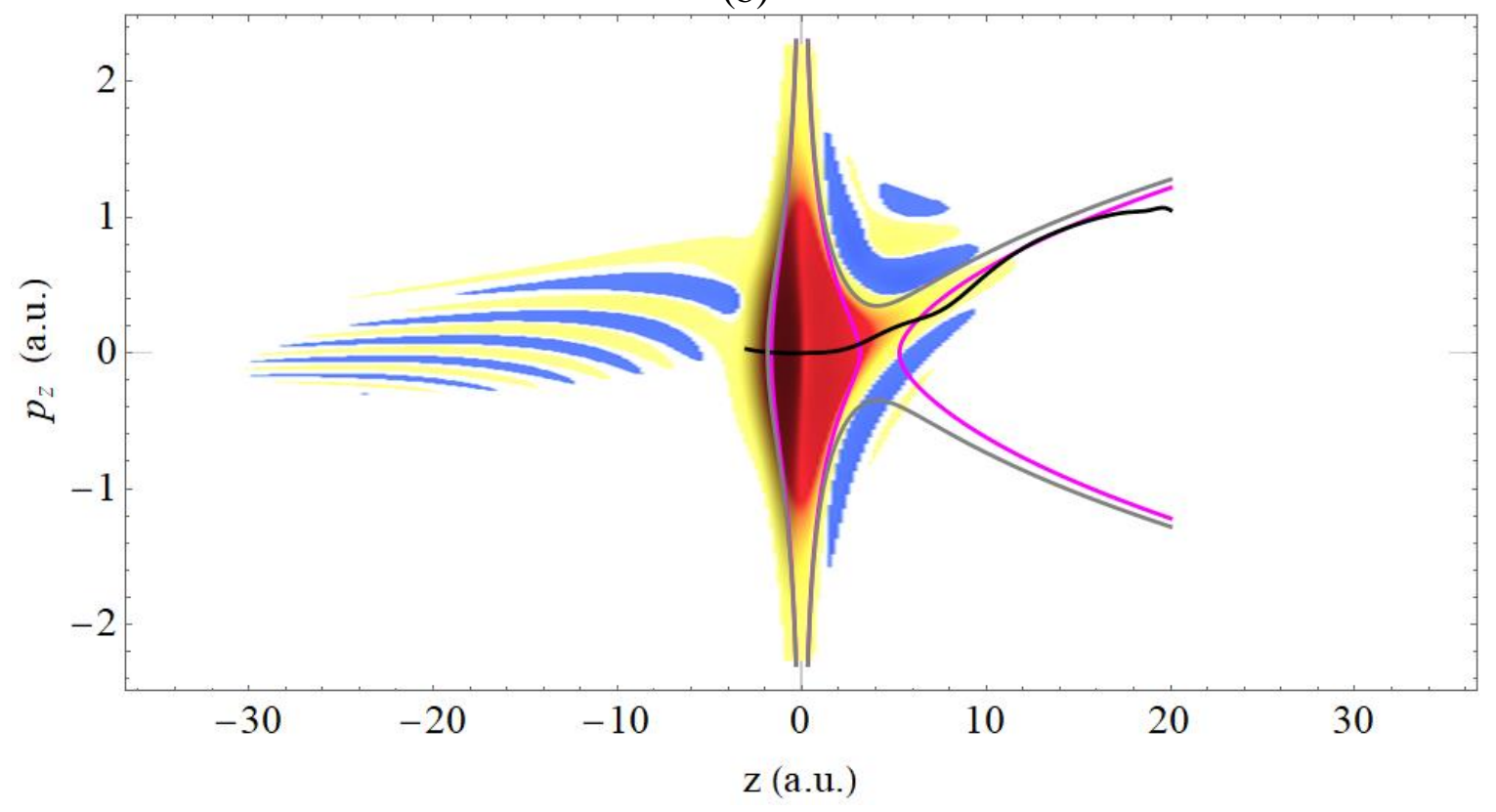

1. ábra

Két pillanatkép a lézerimpulzus hatására a hidrogénatomból kilépő elektron Wigner-függvényéről: (a) 10 atomi időegységgel a lézerimpulzus csúcsa elött és (b) a lézerimpulzus csúcsértékénél. A Wigner-függvényt a kék-fehér-sárga-vörös színskálával ábrázoltuk: a kék negatív, a fehér lényegében zéró, majd a sárgától a vörösig növekvő pozitív függvényértéket jelent. A kvantum-momentum függvény a fekete görbe mutatja. A lila görbe egy olyan részecske fázistér-trajektóriája az atommag és a lézertér pillanatnyi eredő potenciáljában, amelynek energiája megegyezik az elektron energiájának pillanatnyi várható értékével. Ugyanebben a potenciálban a szürke görbén mozogna egy olyan részecske, aminek energiája az elektron energia pillanatnyi várható értékének és szórásának összege. 


\section{Eredmények}

Az 1. ábra alapján mutatjuk be, hogyan segíti a Wigner-függvény és a kvantum-momentum függvény a lézerimpulzus hatására bekövetkező ionizációt elemzését. A $z=0-10$ a.u. tartományban a Wignerfüggvényben kialakuló, ionizációs folyamatot jelző hullámok ill. „nyúlványok” fő vonulatát jól követi a kvantum-momentum függvény, hasonlóan egy korábbi munkánkhoz [12], az alatta és felette kialakuló oszcillációk pedig kvantum-interferenciát jeleznek. A berajzolt állandó energiájú fázistértrajektóriák közül a lila színű egyben az alagút tartomány pillanatnyi határát is megadja, a szürke pedig egy olyan mozgáshoz tartozik, amelyik energiája már elég nagy ahhoz, hogy a pillanatnyi potenciálgáton átjutva vezessen ionizációhoz. Utóbbi alakja jól követi a Wigner-függvény kontúrját az alagút tartományában is.

Az energiaviszonyok gondos numerikus elemzése rávilágít arra, hogy lézerimpulzus hatására az elektron energiájának szórása elég nagy lesz ahhoz, hogy a potenciálgát felett átjutva is megnyílik az ionizáció lehetősége, annak ellenére, hogy az energia várható értéke valójában (kis mértékeben) csökken a kezdeti állapothoz képest, miközben a lézerimpulzus a fö csúcsához közeledik (összhangban a Stark-effektussal). Tehát, bár látszólag mindvégig az alagutazásos ionizáció tartományban maradnak a paraméterek, valójában a potenciálgát felett ionizációs csatorna is megnyílik. Az alagútnak megfelelő illetve azzal kívülről szomszédos fázistér-tartományban a Wigner-függvény hullámvonulatai és oszcillációi valójában az alagúteffektussal illetve a potenciálgát felett átjutó komponensek kvantum-interferenciáját mutatják. Az alagúteffektussal átjutó komponens alagút tartományon kívüli kezdeti kvantum-momentum függvénye lényegében (a numerikus módszer pontosságával) zéró, ahogy azt az alagutazás energiaviszonyai alapján várnánk is (az alagút tartomány kijárata az a hely, ahol a kinetikus energia 0). Ez azonban nem jelenti azt, hogy az alagutazással kijutó komponens ne befolyásolná az eredő kvantum-momentum függvényt: utóbbi tartalmazza az elöbbiből származó interferencia tagokat is.

A kvantum-momentum függvénynek az alagút kijáratában felvett értékét kézenfekvő egy klasszikus részecske-propagáció kezdeti impulzus értékének választani, de ettől kissé eltérő megfontolások is kvalitatívan hasonló fázistér-trajektóriákat eredményeznek. Ezek vizsgálata során szintén jól használható a kvantum-momentum függvény: ha a részecske aktuális helyzete a fázistérben jól követi a kvantum-momentum függvény idöbeli viselkedését, akkor a klasszikus trajektória jó összhangban van a kvantumos időfejlődéssel.

\section{Köszönetnyilvánítás}

A projekt az Európai Unió támogatásával, az Európai Szociális Alap társfinanszírozásával valósul meg, EFOP-3.6.2-16-2017-00005-Ultragyors fizikai folyamatok atomokban, molekulákban, nanoszerkezetekben és biológiai rendszerekben. Az ELI-ALPS projektet (GINOP-2.3.6-15-201500001) az Európai Unió és az Európai Regionális Fejlesztési Alap támogatja. Munkánkat a TUDFO/47138-1/2019-ITM FIKP és a GINOP-2.3.2-15-2016-00036 számú pályázatok is támogatták.

\section{Irodalom}

[1] F. Krausz and M. Ivanov, Rev. Mod. Phys. 81, 163-234 (2009). https://doi.org/10.1103/RevModPhys.81.163

[2] A. S. Landsman and U. Keller, Physics Reports 547, 1 - 24 (2015).

https://doi.org/10.1016/j.physrep.2014.09.002 
[3] P. Eckle, et al., Science 322, 1525-1529 (2008).

https://doi.org/10.1126/science.1163439

[4] D. Shafr, et al.,Nature 485, 343 (2012).

https://doi.org/10.1038/nature11025

[5] A. S. Landsman and U. Keller, J. Phys. B 47, 204024 (2014).

https://doi.org/10.1088/0953-4075/47/20/204024

[6] N. Camus, et al., Phys. Rev. Lett. 119, 023201 (2017).

https://doi.org/10.1103/PhysRevLett.119.023201

[7] U. S. Sainadh, et al., Nature 568, 75-77 (2019).

https://doi.org/10.1038/s41586-019-1028-3

[8] L. Torlina and O. Smirnova Phys. Rev. A 86, 043408 (2012).

https://doi.org/10.1103/PhysRevA.86.043408

[9] H. Ni, et al., Phys. Rev. A 97, 013426 (2018).

https://doi.org/10.1103/PhysRevA.97.013426

[10] M. Lewenstein, et al., Phys. Rev. A 49, 2117 (1994).

https://doi.org/10.1103/PhysRevA.49.2117

[11] Sz. Majorosi and A. Czirják, Computer Physics Communications 208, 9-28 (2016). https://doi.org/10.1016/j.cpc.2016.07.006

[12] A. Czirják, et al., Opt. Commun. 179, 29-38 (2000).

https://doi.org/10.1016/S0030-4018(99)00591-X 